\title{
Association of total-mixed-ration chemical composition with milk, fat, and protein yield lactation curves at the individual level
}

\author{
M. Caccamo, ${ }^{\star 1}$ R. F. Veerkamp,† G. Licitra, ${ }^{\star} \ddagger$ R. Petriglieri, ${ }^{*}$ F. La Terra, ${ }^{\star}$ A. Pozzebon, ${ }^{\star}$ and J. D. Ferguson§ \\ ${ }^{*}$ CoRFiLaC, Regione Siciliana, 97100 Ragusa, Italy \\ †Animal Breeding and Genomics Centre, Wageningen UR Livestock Research, PO Box 65, 8200 AB Lelystad, the Netherlands \\ ‡Dipartimento di Scienze delle Produzioni Agrarie e Alimentari (DISPA), Agriculture Faculty, Catania University, 95123 Catania, Italy \\ §School of Veterinary Medicine, University of Pennsylvania, Philadelphia 19104
}

\section{ABSTRACT}

The objective of this study was to examine the effect of the chemical composition of a total mixed ration (TMR) tested quarterly from March 2006 through December 2008 for milk, fat, and protein yield curves for 27 herds in Ragusa, Sicily. Before this study, standard yield curves were generated on data from 241,153 testday records of 9,809 animals from 42 herds in Ragusa province collected from 1995 to 2008. A random regression sire-maternal grandsire model was used to develop variance components for yields. The model included parity, age at calving, year at calving, and stage of pregnancy as fixed effects. Random effects were herd $x$ test date, sire and maternal grandsire additive genetic effect, and permanent environmental effect modeled using third-order Legendre polynomials. Model fitting was carried out using ASReml. Subsequently, the model with estimated variance components was used to examine the influence of TMR crude protein, soluble $\mathrm{N}$, acid detergent lignin, neutral detergent fiber, acid detergent fiber, starch, and ash on milk, fat, and protein yield curves. The data set contained 46,531 test-day milk yield records from 3,554 cows in the 27 herds recorded during the study period. Initially, an analysis was performed using one dietary component (one-component analysis) within each model as a fixed effect associated with the test-day record closest to the months the TMR was sampled within each herd. An interaction was included with the nutrient component and days in milk. The effect of the TMR chemical component(s) was modeled using a ninth-order Legendre polynomial. The conditional Wald $F$-statistic for the fixed effects revealed significant effects for acid detergent fiber, neutral detergent fiber, crude protein, starch, and their interactions with days in milk on milk, fat, and protein yield. On the basis of these results, a multicomponent

\footnotetext{
Received January 4, 2011.

Accepted June 5, 2012.

${ }^{1}$ Corresponding author: caccamo@corfilac.it
}

analysis was performed in which crude protein, neutral detergent fiber, and starch were simultaneously included in the model with days in milk interactions. Although both analyses revealed that diet composition influenced production responses depending on lactation stage, the multiple-component analysis showed more pronounced effects of starch and neutral detergent fiber relative to crude protein for all traits throughout lactation.

Key words: lactation curve, total mixed ration, testday model

\section{INTRODUCTION}

Lactation curves for milk and milk components in dairy cattle show variation in peak yield and persistency of yield, partially explained by dietary composition and feeding management. It has long been recognized that the increase in milk production decreases for each unit increase in $\mathrm{CP}$ with increased $\mathrm{CP}$ content of the diet (Wu and Satter, 2000; Ipharraguerre et al., 2005). The source of dietary protein influences rumen degradability and has a modifying effect on production responses at moderate (approximately 16\% CP) dietary CP concentrations (Reynal and Broderick, 2003; Ipharraguerre et al., 2005). Furthermore, starch and total energy content of the diet may modify responses to CP. Cabrita et al. (2007) observed that low-protein, low-starch diets decreased DMI and milk production in midlactation cows, but milk production responded to increases in dietary CP, starch, or both. Hristov et al. (2002) observed that starch (energy content) and forage quality significantly affected herd curve traits, whereas Oba and Allen (2003) observed that cows in early lactation fed high-starch diets (32\% of DM) versus low-starch diets $(21 \%$ of $\mathrm{DM})$ produced more milk and protein. In addition, dry corn versus high-moisture corn was associated with higher fat content and fat production in cows fed the high-starch diet.

High-starch diets typically have lower fiber content; therefore, it is difficult to separate the effects of increased starch content from the effects of lower dietary 
fiber. Weiss et al. (2009) observed that the major response in milk volume and milk components was to changes in metabolizable CP supply and not to starch when starch varied from 22.0 to $30.0 \%$ of DM. BrunLafleur et al. (2010) varied energy and CP content across 9 diets fed to lactating dairy cows and observed that production responses to increasing dietary energy were dependent on adequate $\mathrm{CP}$ supply. Production responses to dietary content were greater for cows with high milk production potential, and first-lactation cows responded differently from multiparous cows. This means that the milk production response to changing the diet is dependent on the production potential of the cows, the stage of lactation, management, and the relative concentrations of dietary nutrients. Therefore, a better understanding of the effects of diet on production requires a methodology that controls for lactation stage, management, and cow factors across multiple diets.

Test-day (TD) models provide insight into variation in lactation curves for individual cows and herds and have been used to suggest management advice (Koivula et al., 2007; Caccamo et al., 2008; Halasa et al., 2009). Caccamo et al. (2008) observed that the variation between herd lactation curves for milk and protein yields was highest around the time of peak yield. Subsequently, in an analysis using the TD model to examine factors influencing production at the herd level, Caccamo et al. (2010) observed that animal breed (Holstein-Friesian vs. Brown Swiss) affected peak, persistency, and mean lactation curves for all production traits. Furthermore, the feeding system (TMR vs. separate feeding) influenced peak and mean milk production for all traits and parities. When looking at the average nutrient composition of TMR fed over the year, only $\mathrm{CP}$ and DM content in the diet and their interaction significantly influenced herd curve traits, peak, persistency, and mean milk yield. To be able to extrapolate dietary factors to management advice for individual cows, it is necessary for the diet composition to be linked with individual cow lactation curves. To do this at the field level requires that the TD records be associated with the period that the known diet composition was fed.

A possible reason that associations for other nutrient variables were not observed in the previous study by Caccamo et al. (2010) was that yearly average diet composition was assessed against yearly average herd curves for production. Using the average chemical composition of sampled TMR across the year may have reduced the variability between TMR within the herd over the course of a year and masked some of the effects of nutrient composition, in particular starch and forage quality. It was thought that an investigation of dietary content aligned more closely to TD production might reveal more sensitive relationships between dietary nutrients and milk production. The objective of this study was, therefore, to assess the association of the nutrient composition of the TMR with cow lactation curves for milk, fat, and protein yield and to compare the estimates of a single-component analysis with a model that takes into account all dietary components simultaneously. Using deviations from predictions of production from the TD model for individual cows would control for the effects of herd, parity, stage of lactation, season, and genetics and enable a more sensitive analysis of nutrient effects on production across DIM.

\section{MATERIALS AND METHODS}

\section{Data}

Production data for milk $(\mathrm{kg})$, fat $(\mathrm{g})$, and protein (g) and TMR information were collected from 27 herds located in Ragusa province (Italy) from 2006 through 2008, forming a data set that included 46,531 TD records from 3,554 cows. This data set was used to estimate the association of random individual curves for milk yield with chemical composition of the diets. To estimate variance components for the genetic effects more precisely, a larger data set (full data set) with more animals than the ones with known TMR was necessary. A full data set that included 241,153 TD records from 9,809 animals in 42 herds recorded from 1995 through 2008 was supplied by the local milk recording agency (APA Ragusa, Ragusa, Italy) and used to estimate variance components for milk $(\mathrm{kg})$, fat $(\mathrm{g})$, and protein $(\mathrm{g})$ yield by using a random regression TD model.

For the 27 herds included in the reduced data set, TMR samples were collected every 3 mo from March 2006 through December 2008 and analyzed for ash (AOAC International, 1994), CP (AOAC International, 1994), soluble N (Licitra et al., 1996), ADL (Goering and Van Soest, 1970), NDF (Van Soest et al., 1991), ADF (Goering and Van Soest, 1970), and starch (AOAC International, 1998; method 996.11). All chemical analyses were expressed on a DM basis. Diets were also evaluated using CPM Dairy (version 3.0.8; University of Pennsylvania, Kennett Square, PA, Cornell University, Ithaca, NY, and Miner Agricultural Research Institute, Chazy, NY).

\section{Estimation of Variance Components}

Production TD records for the full data set was processed using a multiple-lactation, single-trait random regression TD model: 


$$
\begin{gathered}
\mathrm{y}_{\mathrm{dklmnoprs}}=\mathrm{ay}_{\mathrm{k}}+\mathrm{ppr}_{\mathrm{l}}+\mathrm{pdd}_{\mathrm{m}}+\mathrm{ym}_{\mathrm{n}}+\mathrm{htd}_{\mathrm{o}} \\
+\sum_{\mathrm{q}=0}^{2} \mathrm{z}_{\mathrm{q}}\left(\mathrm{as}_{\mathrm{qs}}+1 / 2 \mathrm{ams}_{\mathrm{qs}}\right)+\sum_{\mathrm{q}=0}^{2} \mathrm{z}_{\mathrm{q}}\left(\mathrm{pe}_{\mathrm{qs}}\right)+\mathrm{e}_{\mathrm{dklmnoprs}},
\end{gathered}
$$

where $\mathrm{y}_{\mathrm{dklmnoprs}}$ is the yield record (milk, fat, or protein yield) of cow s on DIM d of parity $p$ in herd $r$ within herd test date effect $\mathrm{n}$ and belonging to fixed effect class $\mathrm{k}, \mathrm{l}, \mathrm{m}$, and $\mathrm{n}$ defined as follows: $\mathrm{ay}_{\mathrm{k}}$ is the kth class of age at calving $\times$ year of calving (23 classes); $\operatorname{ppr}_{1}$ is the lth class of parity $\times$ stage of pregnancy $(135$ classes); $\operatorname{pdd}_{m}$ is the mth class of parity $\times$ days dry $(153$ classes); $\mathrm{ym}_{\mathrm{n}}$ is the nth class of year of test $\times$ month of test ( 55 classes); htd $_{\mathrm{o}}$ is the random herd $\times$ test date o (1,386 classes); $z_{q}$ is the $q$ order Legendre polynomial (Kirkpatrick et al., 1990); as $_{\mathrm{qs}}$ is the random additive genetic effect of sire of cow s corresponding to polynomial $\mathrm{q} ; \mathrm{ams}_{\mathrm{qs}}$ is the random additive genetic effect of the maternal grandsire of cow $\mathrm{s}$ corresponding to polynomial $\mathrm{q}$; $\mathrm{pe}_{\mathrm{qs}}$ is the random permanent environmental effect of cow s corresponding to polynomial q; and $e_{\mathrm{dklmnoprs}}$ is the residual belonging to observation $\mathrm{y}_{\text {djklmnoprs. }}$

The pedigree file included 178 sires and 305 grandsires. Unknown parents were assigned to 5 phantom pedigree groups based on their breed (Holstein-Friesian, Brown Swiss, Simmenthal, Modicana, crossbreed, and unknown). Random effects were herd test date, sire and maternal grandsire additive genetic effect, and permanent environmental effect modeled using third-order Legendre polynomials. This order was chosen based on the fit: higher order models gave converging problems and did not explain more variance. Model fitting was carried out using ASREML (Gilmour et al., 2009).

\section{Association Between TMR Chemical Composition and Lactation Curve}

First, a one-component analysis for diet nutrition components (NutUni) was run, in which the variables describing TMR chemical composition were included in the above model one by one. Because TD records were collected monthly whereas TMR were sampled every 3 mo, each TD record was associated with the closest TMR analysis fed to animals immediately before or after the TD. The effect of TMR chemical components was modeled as an interaction with DIM using a ninthorder Legendre polynomial to increase the sensitivity to dietary effects across DIM. Based on the results of the NutUni analysis, a multiple-component analysis (NutMulti) was performed, in which CP, NDF, and starch and their interaction with DIM (fitted as a ninth-order Legendre polynomial) were simultaneously included in the model. The significance of effects was tested using the conditional Wald $F$-statistic in the NutUni and NutMulti models (Gilmour et al., 2009).

Values of parameters estimated in the NutUni and NutMulti models were used to generate lactation curves for milk, fat, and protein yield for the average nutrient value(s) as well as plus and minus 2 standard deviations of nutrient values of the TMR. For the prediction models, average values for fixed effects were held constant, random effects were ignored, and curves were generated for each given value(s) for TMR chemical content, varied as above, obtaining marginal prediction curves between 5 and 305 DIM (Gilmour et al., 2004). In the NutMulti analysis, prediction curves did not include the effects of interactions between chemical nutrients and DIM.

\section{RESULTS}

Descriptive statistics of the chemical composition of TMR samples collected from the 27 farms involved in the project are shown in Table 1, whereas pairwise Pearson correlations among them are shown in Table 2. Mean content of TMR (SD) as a percentage of DM for $\mathrm{CP}, \mathrm{NDF}$, ash, and starch were 15.5 (1.96), 40.4 (4.51), 8.0 (1.14), and 20.3 (3.72; Table 1). Positive correlations $(P<0.001)$ among ADL, ADF, and NDF, and negative correlations between starch and ADL, ADF, and NDF were as expected: higher ADL content was associated with higher content of both NDF and ADF but lower content of starch. In addition, increasing the content of NDF was associated with a decreasing content of starch $(\mathrm{r}=-0.44)$ and $\mathrm{CP}(\mathrm{r}=-0.29)$ in TMR in this study (Table 2). In general, higher fiber content meant less energy and $\mathrm{CP}$ in the diet.

In the NutUni analysis, all chemical parameter values, except ash, and their interactions with DIM influenced $(P<0.001)$ milk lactation curves (Table 3$)$. The main factors influencing fat and protein $(P<0.01)$ were ash, ADF, NDF, CP, and starch (Table 3). Dietary nutrients were both negatively and positively cor-

Table 1. Mean composition of chemical properties of TMR samples collected from 27 farms in Ragusa province

\begin{tabular}{lrcl}
\hline Item $(\%$ of DM) & Mean & $\begin{array}{c}\text { Range } \\
(\text { minimum-maximum })\end{array}$ & SD \\
\hline Ash & 8.0 & $5.9-15.9$ & 1.14 \\
CP & 15.5 & $11.1-32.4$ & 1.96 \\
Soluble N & 31.9 & $11.2-63.7$ & 7.06 \\
ADL & 4.2 & $1.0-11.9$ & 1.25 \\
ADF & 23.1 & $13.7-32.1$ & 3.35 \\
NDF & 40.4 & $24.2-54.5$ & 4.51 \\
Starch & 20.3 & $7.6-32.3$ & 3.72 \\
\hline
\end{tabular}


Table 2. Pearson correlations among chemical properties of TMR samples collected from 27 farms in Ragusa province

\begin{tabular}{lcccccc}
\hline Item $(\%$ of DM) & CP & Soluble N & ADL & ADF & NDF & \multicolumn{1}{c}{ Starch } \\
\hline Ash & -0.06 & 0.05 & 0.11 & $0.20^{* *}$ & 0.05 & $-0.25^{* * *}$ \\
CP & - & 0.02 & -0.09 & $-0.29^{* * *}$ & $-0.35^{* * *}$ & $0.16^{*}$ \\
Soluble N & & - & 0.10 & $0.32^{* * *}$ & $0.14^{*}$ & $-0.34^{* * *}$ \\
ADL & & & - & $0.49^{* * *}$ & $0.35^{* * *}$ & $-0.26^{* * *}$ \\
ADF & & & & - & - & $-0.63^{* * * *}$ \\
NDF & & & & & $-0.44^{* * *}$ \\
Starch & & & &
\end{tabular}

related with each other, as expected. Production effects in NutUni for individual nutrients may be confounded by correlated changes with other dietary concentrations of nutrients. For example, an increase in ash content of the TMR was associated with a reduction in starch content and an increase in ADF content of the TMR. Therefore, production responses in the NutUni models may not be very revealing. Other than $\mathrm{CP}$, increases in dietary content of ash, ADF, NDF, and ADL were all associated with significant decreases in starch content of the TMR (Table 2). Therefore, to more closely examine production influences, multiple-component models were also examined for dietary nutrients.

Lignin and ADF are subcomponents of NDF; NDF represents the main structural carbohydrate in dairy rations. Starch is the major NSC in dairy rations, often comprising 60 to $75 \%$ of the NFC fraction, with the remainder composed of sugars, soluble fibers, and silage acids. Protein forms the other major fermentable organic component of dairy rations. Therefore, $\mathrm{NDF}$, starch, and $\mathrm{CP}$ were selected for inclusion in the multiple-component analysis of dietary components on milk volume and content.

Predicted production curves for milk and fat yields $(\mathrm{kg} / \mathrm{d})$ for TMR content of CP (Figures 1 and 2, respectively), starch (Figures 3 and 4, respectively), and NDF (Figures 5 and 6, respectively) are presented in Figures 1 through 6 . Two sets of curves are plotted within each figure. Production curves with dashed lines represent the NutUni predictions for the effect of the main nutrient by DIM with no other nutrients in the model; the production curves with solid lines present the NutMulti predictions based on inclusion of CP, starch, and NDF. Production curves were generated based on mean nutrient content of TMR (mean: $15.5 \%$ CP, $20.3 \%$ starch, $40.4 \% \mathrm{NDF}$ ), 2 standard deviations below the mean concentration of TMR (low: $11.6 \% \mathrm{CP}, 12.8 \%$ starch, $31.4 \% \mathrm{NDF}$ ), and 2 standard deviations above the mean concentration of TMR (high: $19.4 \%$ CP, $27.7 \%$ starch, $49.5 \% \mathrm{NDF}$ ). In the NutUni prediction models (dashed curves), no other nutrients were included in the model; therefore, the curves represent the singular

Table 3. Probability values for the Wald statistic of the association between TMR chemical components and their interaction with DIM with milk, fat, and protein yield ${ }^{1}$

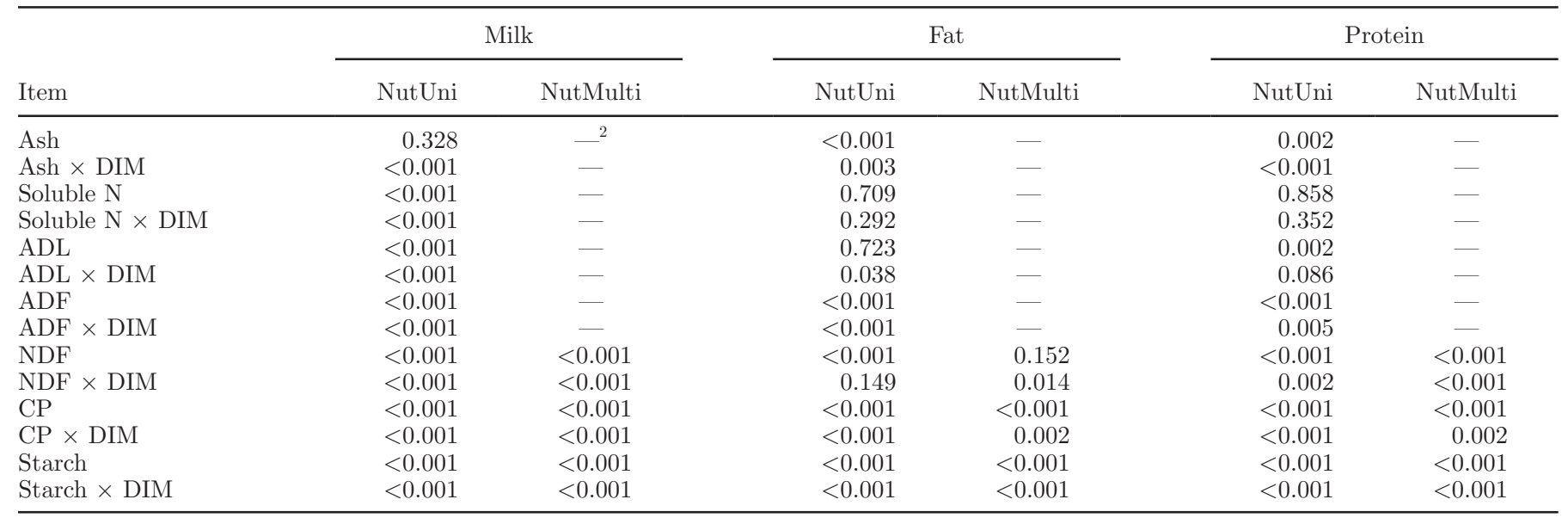

${ }^{1}$ Estimations were performed using a one-component analysis (NutUni) and a multiple-component analysis (NutMulti) for diet nutrient components.

${ }^{2}$ The term was not included in the analysis. 


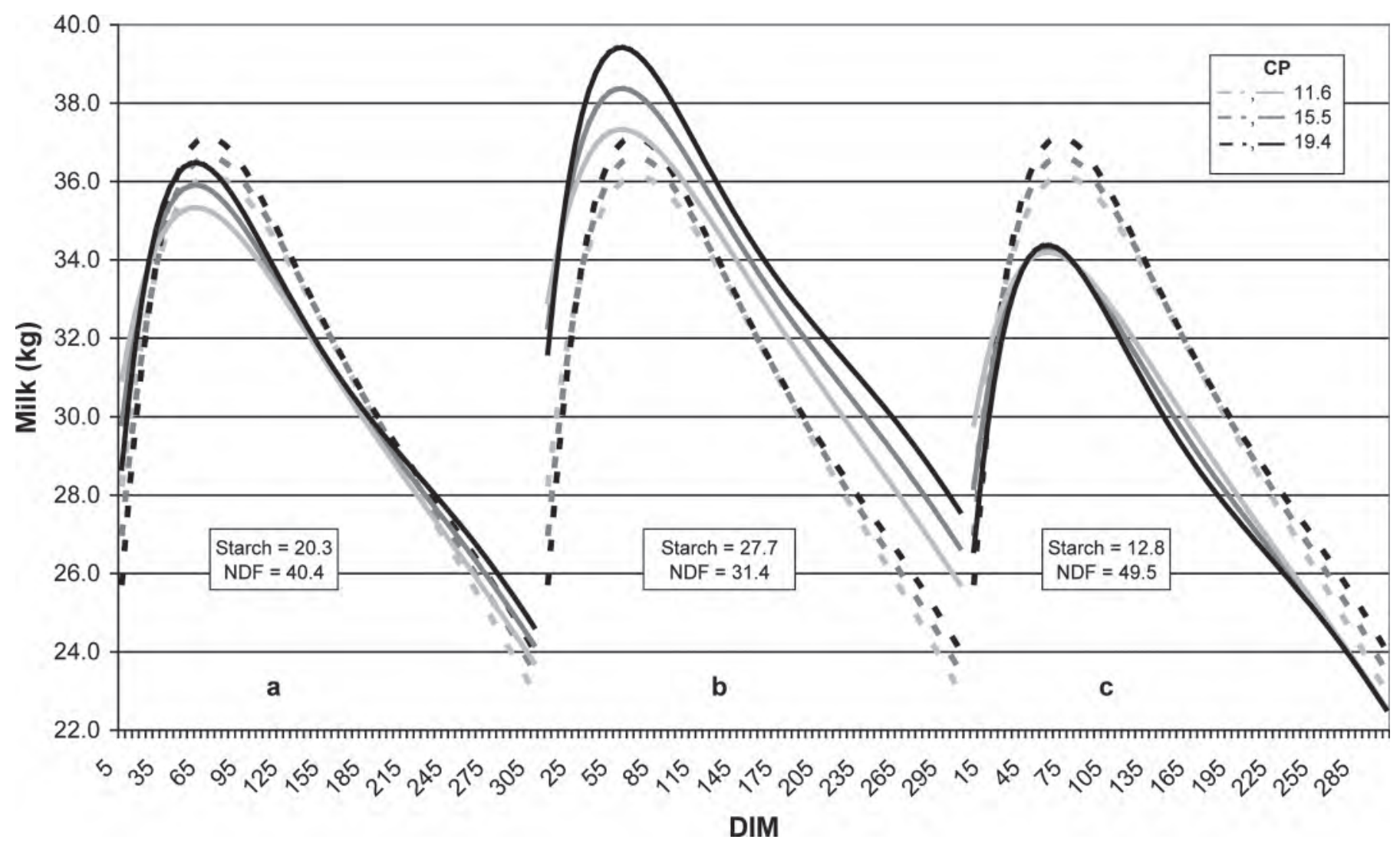

Figure 1. Lactation curves estimated using the NutUni (dashed lines; one-component analysis) and the NutMulti (solid lines; multiplecomponent analysis) model for milk (kg), predicted at different contents (minimum curve = average $-2 \mathrm{SD}$, light gray lines; average curve, dark gray lines; maximum curve $=$ average $+2 \mathrm{SD}$, black lines) of CP in TMR at 3 different combinations with starch and NDF.

effects of changing the dietary content of the nutrient of interest. The production curves predicted from the NutMulti model (solid lines) present the effects of changing the concentration of the nutrient of interest with the dietary concentration of the other 2 nutrients in the model set to mean, high, or low. The change in production curves with other nutrients included in the model (NutMulti) suggests the confounding response one can have when multiple nutrients are not accounted for in the NutUni models. Protein yield curves are not presented because they closely followed the milk volume curves.

Figure 1 shows milk production responses by DIM for changes in CP content (Figure 1). As expected, CP increased peak milk production $(P<0.001)$ in both the NutUni and NutMulti analyses (Table 3, Figure 1). Further, increasing dietary $\mathrm{CP}$ increased milk production in late lactation but had little effect in midlactation in the NutUni curves (Figure 1). However, the effect of changing dietary $\mathrm{CP}$ on milk production across all DIM was influenced by dietary starch and NDF content. With the minimal starch $(12.8 \%$ of DM) and maximal NDF concentration (49.5\% of DM), little production response to changing the $\mathrm{CP}$ concentration was observed (Figure 1, peak c). Only small differences were observed in midlactation, and increased $\mathrm{CP}$ was associated with slightly lower production. With mean starch $(20.3 \%$ of DM) and NDF (40.4\% of DM) concentrations in TMR, increasing the $\mathrm{CP}$ content of diets increased peak milk yield, but little production change was observed after 125 DIM until small increases were apparent after 215 DIM (Figure 1,peak a). With average starch and NDF content, increasing CP from $11.6 \%$ of TMR to $15.5 \%$ increased peak milk yield by approximately $0.5 \mathrm{~kg} / \mathrm{d}$ (Figure 1, peak a). When starch was $27.7 \%$ and NDF was $31.4 \%$ of DM in the TMR, increasing CP from 11.6 to $15.5 \%$ increased peak milk yield by approximately $0.9 \mathrm{~kg} / \mathrm{d}$ (Figure 1, peak b). When CP was increased to $19.4 \%$ of TMR, with mean starch and NDF, peak milk yield increased by an additional $0.6 \mathrm{~kg} / \mathrm{d}$, whereas with the greater starch and lower NDF dietary concentrations, peak yield increased by an additional $0.9 \mathrm{~kg} / \mathrm{d}$ from the mean $\mathrm{CP}$ concentration. In addition, CP increased production throughout 


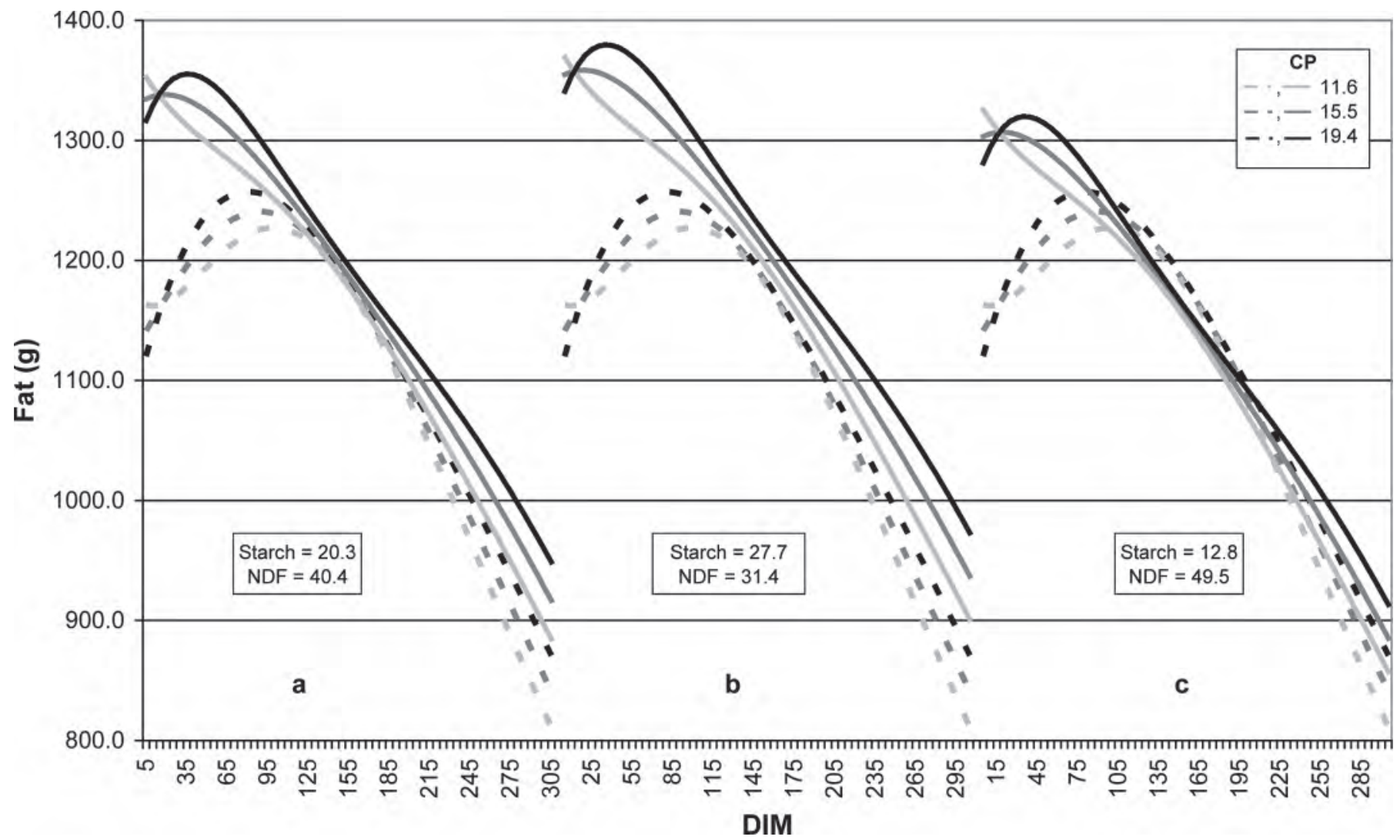

Figure 2. Lactation curves estimated using the NutUni (dashed lines; single-component analysis) and the NutMulti (solid lines; multiplecomponent analysis) model for fat (g), predicted at different contents (minimum curve $=$ average -2 SD, light gray lines; average curve, dark gray lines; maximum curve $=$ average $+2 \mathrm{SD}$, black lines) of CP in TMR at 3 different combinations with starch and NDF.

lactation when starch was high and NDF was low. When starch content was $27.7 \%$ and NDF was $31.4 \%$, increasing dietary $\mathrm{CP}$ increased peak milk yield and yield throughout lactation. For the optimal production response to $\mathrm{CP}$, starch must be high and NDF low.

Figure 2 shows the yield of fat $(\mathrm{g} / \mathrm{d})$ for changing dietary CP. Increasing $\mathrm{CP}$ content of the TMR in the NutUni prediction increased peak fat yield (fewer than 120 DIM), and then after 200 DIM to 305 DIM (Figure 2, dashed lines). Very early in lactation, at fewer than 20 DIM, increasing dietary $\mathrm{CP}$ was associated with lower fat yields (Figure 2, dashed line curves). In the NutMulti model, increasing TMR CP increased fat yield throughout lactation; however, responses were greatest at peak milk yield and after 200 DIM for all starch and NDF concentrations. However, the yield increases in milk fat were greatest for high-starch and low-NDF TMR content, with responses to increasing $\mathrm{CP}$ being intermediate with mean starch and mean NDF content in the TMR (Figure 2, solid lines in peaks $\mathrm{a}, \mathrm{b}$, and c). An inverse effect of $\mathrm{CP}$ content on fat yield in the first $20 \mathrm{~d}$ of lactation was also apparent in the NutMulti models. This maybe an artifact because few TD records are collected from cows at fewer than 20 DIM; however, mobilization of tissue reserves may also confound responses to dietary nutrients within this time period.

Increasing dietary starch always increased milk yield throughout lactation DIM in NutUni and NutMulti (Figure 3). When CP was $11.6 \%$ and NDF was $49.5 \%$, increasing dietary starch from 11.6 to $20.3 \%$ of DM increased milk yield by approximately $0.4 \mathrm{~kg} / \mathrm{d}$. Further increasing starch to $27.7 \%$ of DM when CP was low and NDF was high increased milk yield an additional 0.4 $\mathrm{kg} / \mathrm{d}$ (Figure 3, peak c). When CP and NDF were at the mean dietary concentrations, milk yield increased by $1.4 \mathrm{~kg} / \mathrm{d}$, almost 3 times the response when $\mathrm{CP}$ was low and NDF was high, when starch was increased from a low to mean concentration in the TMR (Figure 3, peak a). Further increasing starch to $27.7 \%$ of DM increased milk yield by an additional $1.4 \mathrm{~kg} / \mathrm{d}$. When CP was high and NDF was low, increasing dietary starch to $20.3 \%$ of DM from a low concentration increased milk yield by $2.2 \mathrm{~kg} / \mathrm{d}$ (Figure 3, peak b). Increasing starch 


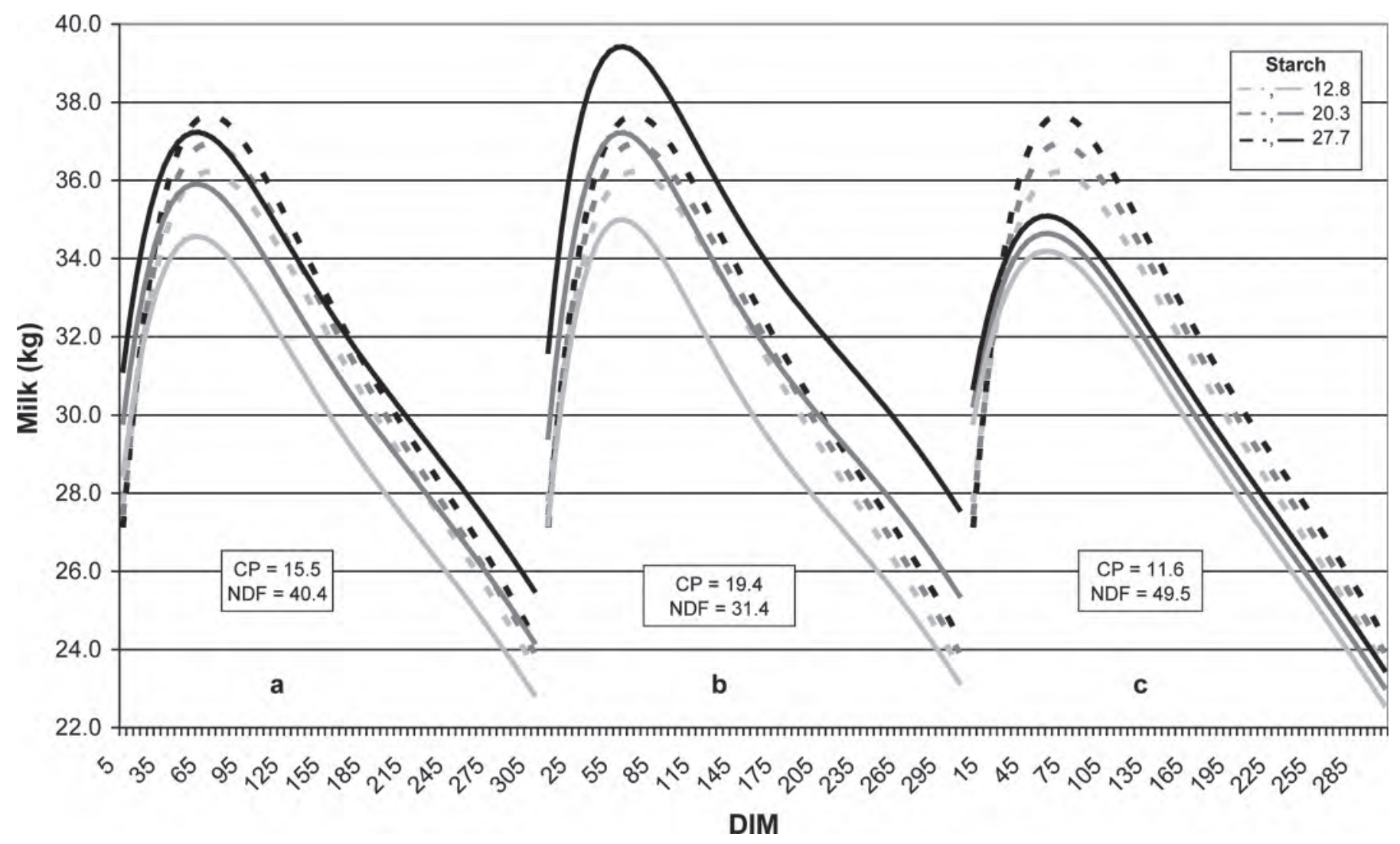

Figure 3. Lactation curves estimated using the NutUni (dashed lines; single-component analysis) and the NutMulti (solid lines; multiplecomponent analysis) model for milk (kg), predicted at different contents (minimum curve = average -2 SD, light gray lines; average curve, dark gray lines; maximum curve $=$ average $+2 \mathrm{SD}$, black lines) of starch in TMR at 3 different combinations with CP and NDF.

to a high concentration increased milk yield by an additional $2.2 \mathrm{~kg} / \mathrm{d}$. Therefore, the response to starch was enhanced by increased dietary $\mathrm{CP}$ and decreased dietary NDF concentration in the TMR.

In the NutUni model, increasing dietary starch influenced milk fat yield in very early lactation (Figure 4, dashed lines). The high concentration of dietary starch was associated with low fat yields in the first month of lactation (Figure 4, dashed lines). Low dietary starch was associated with greater fat yields in early lactation in the NutUni model. However, these associations were removed in the NutMulti model. Increasing dietary starch had little influence on milk fat yield with low CP and high NDF in the TMR (Figure 4c, solid lines). When CP and NDF were included in the model at mean concentrations, the response in milk fat yield to increasing starch content was approximately $30 \mathrm{~g}$ when starch content increased from low $(12.8 \%)$ to mean $(20.3 \%)$ and from mean to high $(27.7 \%$; Figure 4 , peak a), and peak fat yield was approximately 30 DIM. When CP was high and NDF was low, the response to increasing starch content from low (12.8\%) to mean
(20.3\%) TMR concentration was approximately $60 \mathrm{~g}$ of fat yield throughout lactation (Figure 4, peak b). Further increasing starch to high concentration (27.7\%) increased fat yield by an additional $60 \mathrm{~g} / \mathrm{d}$ throughout lactation (Figure 4, peak b, solid lines). Peak fat yield to increasing starch was approximately 50 DIM when $\mathrm{CP}$ was high and NDF was low (Figure 4, peak b). Increasing starch increased fat yield when $\mathrm{CP}$ and NDF were at least mean to high and low, respectively, in TMR.

In the NutUni model for NDF, low NDF was associated with greater milk yields than mean and highNDF TMR concentrations (Figure 5, dashed lines). The effect of changing NDF content in the TMR was more apparent when CP and starch were high in TMR (Figure 5, peaks a, b, and c). The response to decreasing NDF was approximately $1 \mathrm{~kg} / \mathrm{d}$ when reducing the concentration from 49.5 to $40.4 \%$ when $\mathrm{CP}$ and starch were high in TMR (Figure 5, peak b), whereas the milk response was approximately $0.5 \mathrm{~kg} / \mathrm{d}$ when $\mathrm{CP}$ and starch were mean in TMR (Figure 5, peak a), and the milk response to decreasing NDF content was less ap- 


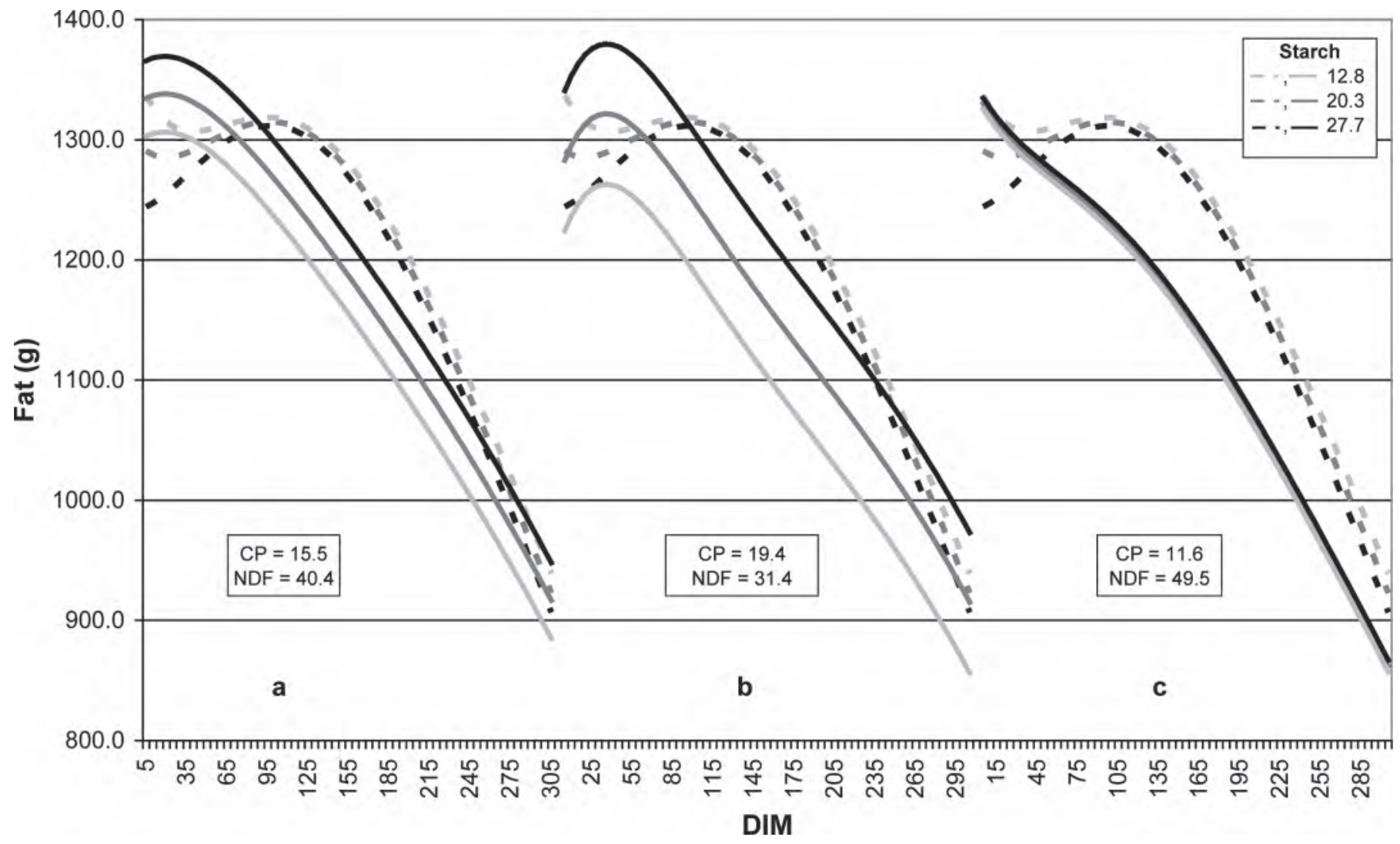

Figure 4. Lactation curves estimated using the NutUni (dashed lines; single-component analysis) and the NutMulti (solid lines; multiplecomponent analysis) model for fat $(\mathrm{g})$, predicted at different contents (minimum curve $=$ average $-2 \mathrm{SD}$, light gray lines; average curve, dark gray lines; maximum curve $=$ average $+2 \mathrm{SD}$, black lines) of starch in TMR at 3 different combinations with CP and NDF.

parent when CP and starch were low in TMR (Figure 5 , peak c). Milk yield increased by an additional $1 \mathrm{~kg} / \mathrm{d}$ when NDF was reduced from 40.4 to $31.4 \%$ when CP and starch were high in the TMR, whereas the response was approximately $0.5 \mathrm{~kg} / \mathrm{d}$ when the TMR had mean $\mathrm{CP}$ and NDF concentrations (Figure 5, peak a).

Low NDF content increased fat yield by approximately $9 \mathrm{~g} / \mathrm{d}$ compared with mean NDF TMR content and by approximately $18 \mathrm{~g} / \mathrm{d}$ compared with high-NDF TMR content throughout lactation in the NutUni model (Figure 6). In the NutMulti model, the influence of changing TMR NDF content on fat yield was reversed when responses for low TMR content of $\mathrm{CP}$ and starch were compared with high TMR content of CP and starch (Figure 6, peaks a, b, and c). When starch and $\mathrm{CP}$ were low, decreasing the NDF from high to mean content increased fat yield by $30 \mathrm{~g} / \mathrm{d}$ throughout lactation (Figure 6, peak c), and when NDF decreased from mean to low content, fat yield increased by an additional $30 \mathrm{~g} / \mathrm{d}$ (Figure 6, peak c). The response to altered NDF when starch and CP were at mean concentrations in the TMR was interesting. Fat yields for the $3 \mathrm{NDF}$ concentrations were almost superimposed
(Figure 6, peak a), and yield had a peak at 20 to $30 \mathrm{~d}$ postcalving. When starch and CP TMR concentrations were high, high NDF was associated with the greatest fat yield (Figure 6, peak b) and low NDF content was associated with the lowest fat yield relative to the mean and high-NDF content (Figure 6, peak b).

Dietary starch was the major dietary factor influencing all traits $(P<0.001)$ throughout lactation in both the NutUni and NutMulti analyses (Table 3). Increasing starch had a significant direct effect on milk production throughout lactation. However, when also accounting for CP and NDF in the NutMulti analysis, the effect of starch became much more pronounced when CP was high and NDF was low. Taken together, increasing starch content of the TMR had approximately twice the influence on milk volume compared with increasing CP (compare Figure 1, peaks a and b, with Figure 3, peaks a and b). The more pronounced effect of starch on fat yield is also apparent when comparing Figure 2, peaks a and b, with Figure 4, peaks a and $\mathrm{b}$. The effect of dietary $\mathrm{CP}$ on milk yield and fat yield is fully expressed when starch is high and NDF is low. 


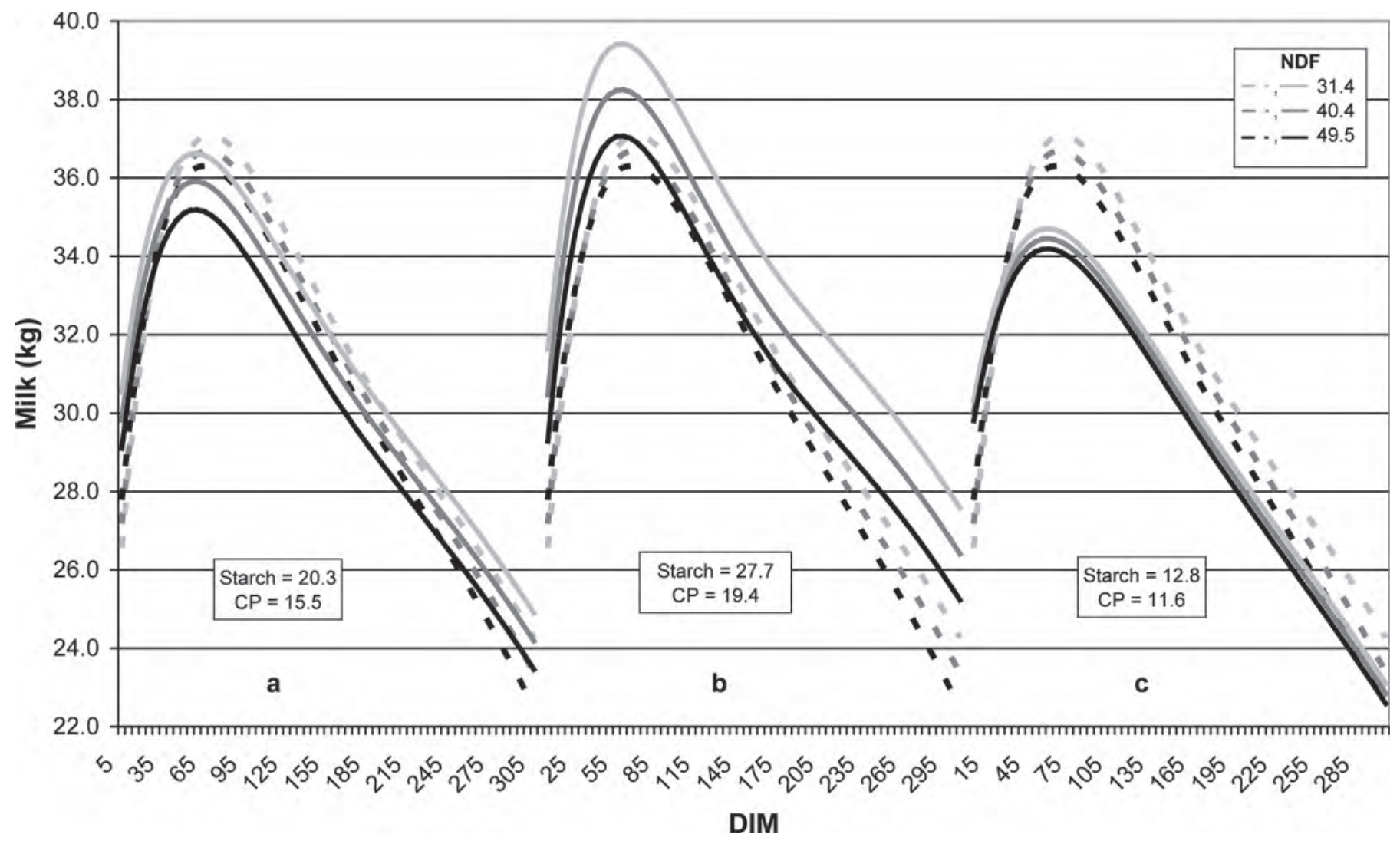

Figure 5. Lactation curves estimated using the NutUni (dashed lines; single-component analysis) and the NutMulti (solid lines; multiplecomponent analysis) model for milk (kg), predicted at different contents (minimum curve = average $-2 \mathrm{SD}$, light gray lines; average curve, dark gray lines; maximum curve $=$ average $+2 \mathrm{SD}$, black lines) of NDF in TMR at 3 different combinations with starch and CP.

\section{DISCUSSION}

The effects of nutritional composition on lactation curves for milk, fat, and protein yield have been investigated extensively in experiments with varying nutritional quality (Wu and Satter, 2000; Ipharraguerre et al., 2005; Brun-Lafleur et al., 2010). In this study, we used a different kind of approach, in which we retrospectively explained the variation in the lactation curves attributable to diet composition. The disadvantages of our approach was that the TMR composition was examined only 4 times a year for nutritional components, and these were associated with the closest TD milk yield. However, the advantage was that a large number of herds and animals were included in an analysis that controlled for genetic and herd-yearseason effects. We were also able to investigate many nutritional components simultaneously by quantifying the substitution effect on production (i.e., the change in production attributable to increasing or decreasing one diet component when the other components were fixed at 3 dietary concentrations) under the assumption that animals fed free choice eat to their maximal capacity. Several experiments would have been needed to investigate these interactions between components.

\section{Nutritional Effects of Single Components}

Results of responses in this study suggest that changes in milk yield attributable to $\mathrm{CP}$ and NDF were dependent on dietary content of starch. When starch was high and NDF was low, the response to increasing $\mathrm{CP}$ content of the TMR was most prominent. Likewise, when starch and $\mathrm{CP}$ were high, the milk response to decreasing dietary NDF was greatest. Overall, starch content of the TMR was the most important element in determining increased milk and fat yields. Increasing starch always increased milk and fat yields. Dietary CP was the second most important factor. However, the response to $\mathrm{CP}$ was strongly dependent on starch and NDF content of the TMR. Effects of CP on yield were dependent on mean to high starch and mean and low NDF content of the TMR. Reducing the TMR NDF content increased the yield of milk, but the effects were most pronounced when starch and CP were high. Fat yields were increased by dietary starch, particularly 


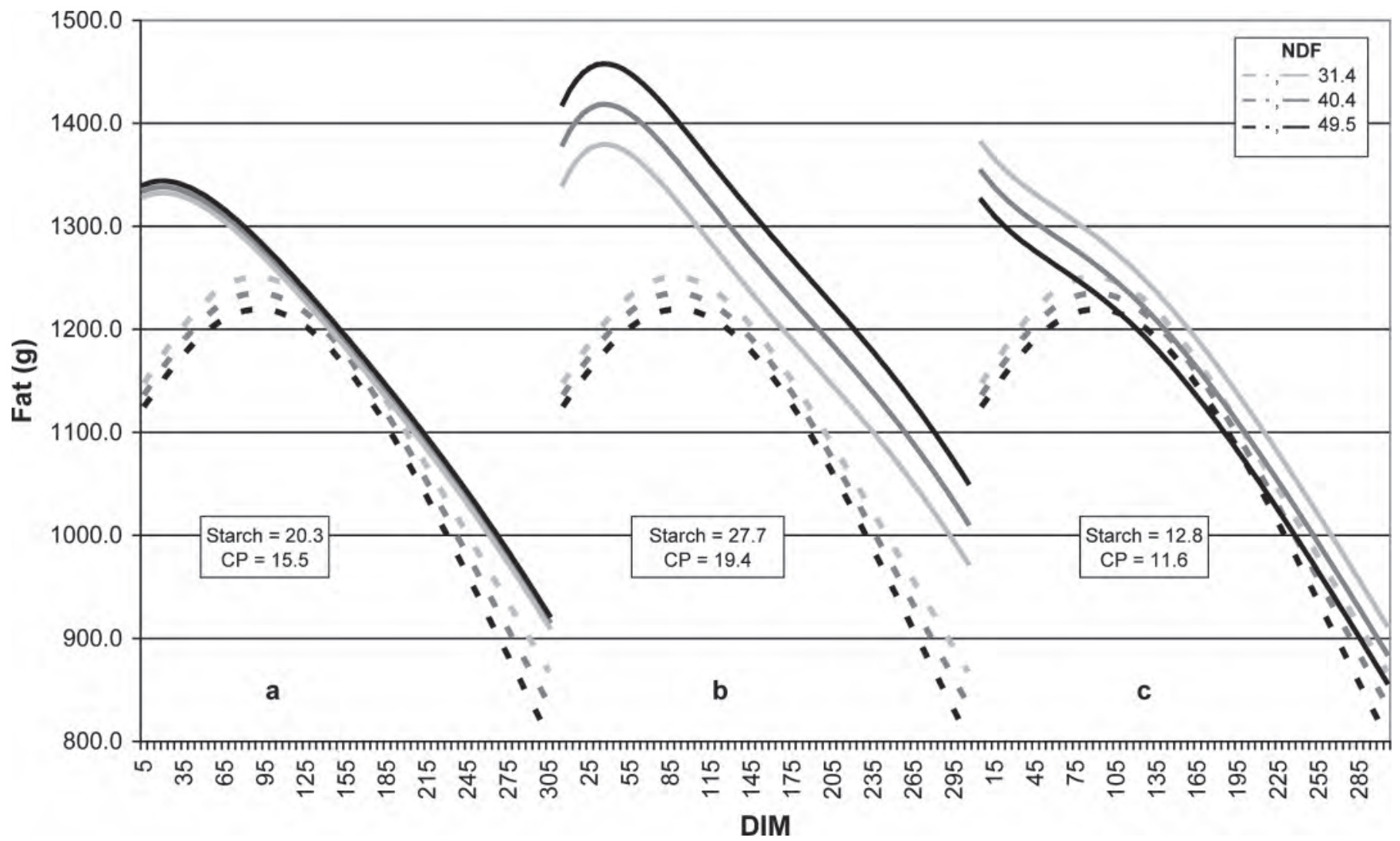

Figure 6. Lactation curves estimated using the NutUni (dashed lines; single-component analysis) and the NutMulti (solid lines; multiplecomponent analysis) model for fat (g), predicted at different contents (minimum curve $=$ average -2 SD, light gray lines; average curve, dark gray lines; maximum curve $=$ average $+2 \mathrm{SD}$, black lines) of NDF in TMR at 3 different combinations with starch and CP.

when $\mathrm{CP}$ and NDF concentrations were mean concentrations or CP was high and NDF was low in the TMR. Likewise, increasing CP increased fat yield, but not to the extent of starch, when NDF was mean or low and $\mathrm{CP}$ was mean or high. When starch and $\mathrm{CP}$ were low in TMR, then decreasing NDF content increased fat yields, but when $\mathrm{CP}$ and starch were high, then increasing NDF content increased fat yield.

Despite the difference in methodology, the effects of nutritional components on lactation curves found in this study were consistent with the reported literature, which lends credibility to the multiple-component models. Increasing CP content increased peak milk yield and had small effects in late lactation. Responses to changing concentrations of $\mathrm{CP}$ in the single-nutrient model and the multiple-nutrient model under average conditions were similar. Wu and Satter (2000) observed that increasing dietary CP from 15 to 17 to $18 \%$ increased peak milk yield, and $17 \% \mathrm{CP}$ throughout lactation was recommended for maximizing total yield. However, they found that after 14 wk of lactation, CP could be reduced to $16 \%$ of the diet with only small reductions in yield and significant reductions in total $\mathrm{N}$ excretion.
The milk curves in this paper suggest dietary CP influences peak milk production, and dietary concentration of $\mathrm{CP}$ in midlactation was not very important until after 250 DIM, and even then effects on milk production were small. Law et al. (2009) found that an increase in dietary $\mathrm{CP}$ concentration increased milk, fat, and protein yield in early lactation (d 1 to 150), arguing that thereafter, CP concentration can be reduced with no detrimental effects on animal performance. Holter et al. (1997) found high correlations of dietary CP with milk and milk protein yield ( $\mathrm{r}=42$ and $38 \%$, respectively). However, Broderick (2003) reported that increasing dietary $\mathrm{CP}$ concentration above $167 \mathrm{~g} / \mathrm{kg}$ of DM had only small positive effects on DMI, with no increases in milk, fat, or protein yield. Similarly, Cunningham et al. (1996) found that increasing the amount of CP in diets had only small effects on the pattern of AA in duodenal digesta because of variable effects of rumen degradation of dietary CP. Consequently, when diets contained amounts of $\mathrm{CP}$ above $16 \%$ of DM, compared with a diet of $14.5 \% \mathrm{CP}$, yields of milk and milk components improved. However, increasing dietary CP to $18 \%$ of DM did not improve milk or milk component yields. 
Milk production improved when dietary CP supplied higher flows of $\mathrm{N}$ and essential AA to the intestine.

Flow of nonammonia $\mathrm{N}$ and essential AA to the small intestine is a function of DMI, CP content of the ration, rumen degradation of feed protein, and the flow of microbial protein from the rumen. Ipharraguerre et al. (2005) observed that cows consuming adequate energy and other nutrients received sufficient AA flow to the small intestine when consuming 14 to $18 \% \mathrm{CP}$ diets and observed no production response in cows consuming adequate energy. Therefore, $\mathrm{CP}$ effects on milk production may be apparent only at peak milk production, when energy intake is limiting, and may not be significantly apparent in latter lactation, when energy intake is not limiting. Furthermore, because NDF and starch content of the diet influence microbial growth, the influence of dietary $\mathrm{CP}$ on small intestinal AA flow is dependent on these other dietary constituents. In this study, dietary CP of $19.4 \%$ was associated with higher peak milk yield compared with 15.5 and $11.6 \%$ dietary CP. However, it appeared advantageous to feed this amount of $\mathrm{CP}$ only in early lactation, and responses to $\mathrm{CP}$ were dependent on increasing starch and reducing NDF.

Starch content of the TMR became the most significant factor influencing milk, fat, and protein yield over the entire lactation. Increasing starch content of the TMR elevated the entire lactation curve and increased fat yield throughout lactation. Protein yield followed a pattern similar to fat yield (data not shown). Therefore, starch content of the TMR is an important factor influencing milk volume and fat and protein yields. Starch influences not only potential energy supply but also metabolizable CP supply by association with rumen microbial synthesis.

Feeding more than 20\% starch throughout lactation would be recommended, based on the results of this study. Caution should be exercised in interpreting $27.7 \%$ as the optimum starch content to feed because only 3 dietary concentrations of starch were explored in this study $(12.8,20.3$, and $27.7 \%$ ): between 20 and $27 \%$ starch, contents that are intermediate and more economically optimal may be available, although these were not explored in this paper.

\section{Interactions Between Components}

It is impossible to alter one nutrient concentration because values need to sum to $100 \%$ of the diet. We chose to examine CP, starch, and NDF because these are the more common nutrients nutritionists are attempting to control in dairy rations. Responses to high concentrations of NDF, CP, and starch should be interpreted cautiously because these values sum to $96.7 \%$ of DM, which is unlikely to be observed in many herd situations. Mean ash was $8.0 \%$ and mean fat content was $4.4 \%$ of the TMR in this study (data not shown). The low end of the range of ash was $5.9 \%$, and fat was $2.2 \%$ (data not shown); therefore, the high TMR content for CP, NDF, and starch could not exist together. Given the correlations in Table 2, as NDF increases, starch and CP in the TMR would decrease (approximately at equal magnitudes), whereas $\mathrm{CP}$ and starch (more weakly) would tend to change in concert with each other (Table 2). Therefore, increases in NDF should be focused on curves with reducing $\mathrm{CP}$ and starch content in the TMR.

Although increasing starch had a significant effect on milk production throughout lactation in both analyses, a more pronounced effect for starch was found in the NutMulti model than in the NutUni model. Brun-Lafleur et al. (2010) found similar results when assessing the effect of the energy $\times$ protein interaction on milk yield: this interaction resulted in a sharper response of milk yield to energy supply for high levels than for low levels of CP supply. When CP is at an average concentration in the diet, increasing starch had a slightly larger effect on increasing the peak yield than did increasing $\mathrm{CP}$ when starch was at an average concentration. This could be due to an effect of balancing of AA, glucose, and acetate: when $\mathrm{CP}$ content is increased at the expense of starch, some of the AA can be used for glucose, but not vice versa. On a nutrient efficiency basis, increasing starch in moderate-CP diets to increase peak milk yield would be a more attractive strategy than increasing $\mathrm{CP}$, and less $\mathrm{N}$ would be wasted in urinary excretion. Reynolds et al. (2001) infused increasing amounts of starch into the duodenum and observed decreases in urinary $\mathrm{N}$ output along with increases in milk production and body tissue deposition. As lactation proceeds, increasing $\mathrm{CP}$ would not benefit production unless starch is high. For example, at approximately 150 DIM, if starch and NDF are mean, milk yield is slightly greater than $32 \mathrm{~kg}$ of milk/d for all CP concentrations (Figure 1, peak a). However if starch is high and NDF is low, then milk yield is slightly greater than $36 \mathrm{~kg} / \mathrm{d}$ for high CP concentration, slightly lower than $36 \mathrm{~kg} / \mathrm{d}$ for mean CP concentration, and approximately $35 \mathrm{~kg} / \mathrm{d}$ for low CP concentration. Therefore, milk yield increased more by high starch and low NDF than by changing CP (Figure 1, peak b). Contrary to this study, Broderick (2003) found no energy $\times$ protein interaction effect on milk production. Similarly, Cabrita et al. (2007) observed that increasing CP from approximately $13.5 \%$ to approximately $15.5 \%$ when starch was $15 \%$ of DM resulted in production responses similar to increasing starch to $23.9 \%$ of DM when CP was $13.5 \%$. These studies were designed to examine starch $\times \mathrm{CP}$ 
interactions, whereas the present study is based on an a priori decision to examine milk curves for diets fed to animals in commercial herds.

Starch nutrient content of $27.7 \%$ appeared to have the greatest effect on milk, fat, and protein yield. Starch has the dual effect not only of supplying energy, but also of being a significant source of protein for the cow because of rumen utilization of starch for microbial CP synthesis. As long as sufficient $\mathrm{N}$ is present in the rumen, fermentation of starch can provide significant amounts of microbial CP. The NRC (2001) uses a conversion of $130 \mathrm{~g}$ of bacterial $\mathrm{CP} / \mathrm{kg}$ of TDN. Increasing starch from 20.3 to $27.7 \%$ would potentially increase bacterial CP supply by 45 to $60 \mathrm{~g} / \mathrm{d}$ if NDF remains $40 \%$ of DM. A confounding factor in actual fact is that when starch is increased, some other dietary components must change because these are expressed as a percentage of DM, which has to add to $100 \%$. However, in the responses in this paper, increasing starch to $27.7 \%$ should be accompanied with a reduction in NDF to 31.4 from $40.4 \%$. This change is a trade-off of a more rumen-fermentable carbohydrate (starch) for a less rumen-degradable carbohydrate (NDF). In this study, if NDF is $31.4 \%$ of DM in the TMR, CP is $18.5 \%$, and starch is $24 \%$, if CP is increased to $19.5 \%$, milk would increase by approximately $0.2 \mathrm{~kg} / \mathrm{d}$. However, if starch were increased to $25 \%$ with CP at $18.5 \%$, milk would increase by $0.5 \mathrm{~kg} / \mathrm{d}$ (combining responses in milk curves from Figures 1 and 3). Fat yield would change very little with the increase in $\mathrm{CP}$ in this scenario, but increasing starch would increase fat yield by approximately $8 \mathrm{~g} / \mathrm{d}$ (combining Figures 2 and 4 ). A unit increase in dietary starch content has a greater effect on milk and fat yield than does a unit increase in CP. Reduction in NDF typically means a reduction in forage in the ration, for which a limit exists regarding how much forage can be reduced and still maintain rumination and a rumen mat of long particles. A minimum NDF concentration of $31.4 \%$ should be adequate because the NRC (2001) recommends a minimum of 25 to $33 \%$ dietary NDF.

The change in production effect when the other nutrients are included in the model found in this study suggests the confounding response one can have when multiple nutrients are not accounted for. The integration of information from the NutMulti curves for CP, starch, and NDF suggests that diets should contain moderate $\mathrm{CP}$, high starch, and low NDF content in the first 150 DIM to maximize milk volume and fat and protein yields. In this study, those nutrient concentrations would be $19.4 \% \mathrm{CP}, 27.7 \%$ starch, and $31.4 \%$ NDF. After 150 DIM, production was always higher with the $27.7 \%$ starch diet. Fat and protein yields were not influenced by $\mathrm{CP}$ content in late lactation, and milk volume was influenced only to a modest extent. Combined, after 150 DIM it appears that diets with $27.7 \%$ starch, $40.4 \% \mathrm{NDF}$, and 11.5 to $15.5 \% \mathrm{CP}$ content would maintain yields of milk, fat, and protein. In any case, this study has developed a statistical model able to describe variation in milk and milk component yields when the diet composition of the TMR changes. Results from extreme conditions have to be carefully interpreted because only 3 dietary conditions for each component were examined: intermediate values (not explored in this study) would be more appropriate in terms of feed costs and production response while preventing metabolic disorders.

\section{CONCLUSIONS}

Using data collected at farms in a field study with a modeling approach, effects of CP, NDF, and starch on individual lactation curves for milk, fat, and protein could be reproduced. Fitting the interaction between the diet components showed that starch had the greatest effect on milk, fat, and protein production when $\mathrm{CP}$ and NDF contents were at a high and low value, respectively. To accomplish feeding the appropriate ration based on DIM and production, farms should group cows accordingly to minimize under- and overfeeding.

\section{ACKNOWLEDGMENTS}

The authors thank Giuseppe Giurdanella for data editing. Financial support was provided by the Assessorato Agricoltura e Foreste della Regione Siciliana (Palermo, Italy).

\section{REFERENCES}

AOAC International. 1994. Official Methods of Analysis. 15th ed. AOAC International, Arlington, VA.

AOAC International. 1998. Official Methods of Analysis of AOAC International. 4th rev. 16th ed. AOAC International, Arlington, VA.

Broderick, G. A. 2003. Effects of varying dietary protein and energy levels on the production of lactating dairy cows. J. Dairy Sci. 86:1370-1381.

Brun-Lafleur, L., L. Delaby, F. Husson, and P. Faverdin. 2010. Predicting energy $\times$ protein interaction on milk yield and milk composition in dairy cows. J. Dairy Sci. 93:4128-4143.

Cabrita, A. R. J., R. J. B. Bessa, S. P. Alves, R. J. Dewhurst, and A. J. M. Fonseca. 2007. Effects of dietary protein and starch on intake, milk production, and milk fatty acid profiles of dairy cows fed corn silage-based diets. J. Dairy Sci. 90:1429-1439.

Caccamo, M., R. F. Veerkamp, G. de Jong, M. H. Pool, R. Petriglieri, and G. Licitra. 2008. Variance components for test-day milk, fat and protein yield, and somatic cell scores for analyzing management information. J. Dairy Sci. 91:3268-3276.

Caccamo, M., R. F. Veerkamp, J. D. Ferguson, R. Petriglieri, F. La Terra, and G. Licitra. 2010. Associations of breed and feeding management with milk production curves at herd level using a random regression test-day model. J. Dairy Sci. 93:4986-4995. 
Cunningham, K. D., M. J. Cecava, R. Johnson, and P. A. Ludden. 1996. Influence of source and amount of dietary protein on milk yield by cows in early lactation. J. Dairy Sci. 79:620-630.

Gilmour, A., B. Cullis, S. Welham, B. Gogel, and R. Thompson. 2004. An efficient computing strategy for prediction in mixed linear models. Comput. Stat. Data Anal. 44:571-586.

Gilmour, A. R., B. J. Gogel, B. R. Cullis, and R. Thompson. 2009. ASReml User Guide. NSW Dept. Primary Industries, Orange, Australia.

Goering, H. K., and P. J. Van Soest. 1970. Forage fiber analysis (apparatus, reagent, procedures and some applications). Agric. Handbook No. 379. US Dept. Agric., Washington, DC.

Halasa, T., M. Nielen, A. P. W. De Roos, R. Van Hoorne, G. de Jong, T. J. G. M. Lam, T. van Werven, and H. Hogeveen. 2009. Production loss due to new subclinical mastitis in Dutch dairy cows estimated with a test-day model. J. Dairy Sci. 92:599-606.

Holter, J. B., J. W. West, and M. L. McGilliard. 1997. Predicting ad libitum dry matter intake and yield of Holstein cows. J. Dairy Sci. 80:2188-2199.

Hristov, A. N., W. J. Price, and B. Shafii. 2002. Dietary factors influencing milk yield and milk protein yield in dairy cows. Pages 147-166 in Proc. Pacific Northwest Animal Nutr. Conf., Vancouver, British Columbia, Canada. C R Press, Portland, OR.

Ipharraguerre, I. R., J. H. Clark, and D. E. Freeman. 2005. Varying protein and starch in the diet of dairy cows. I. Effects on ruminal fermentation and intestinal supply of nutrients. J. Dairy Sci. 88:2537-2555.

Kirkpatrick, M., D. Lofsvold, and M. Bulmer. 1990. Analysis of the inheritance, selection and evolution of growth trajectories. Genetics 124:979-993.

Koivula, M., J. I. Nousiainen, J. Nousiainen, and E. A. Mäntysaari. 2007. Use of herd solutions from a random regression test-day model for diagnostic dairy herd management. J. Dairy Sci. 90:2563-2568.

Law, R. A., F. J. Young, D. C. Patterson, D. J. Kilpatrick, A. R. G. Wylie, and C. S. Mayne. 2009. Effect of dietary protein content on animal production and blood metabolites of dairy cows during lactation. J. Dairy Sci. 92:1001-1012.

Licitra, G., T. M. Hernandez, and P. J. Van Soest. 1996. Standardization of procedures for nitrogen fractionation of ruminant feeds. Anim. Feed Sci. Technol. 57:347-358.

NRC. 2001. Nutrient Requirements of Dairy Cattle. 7th rev. ed. NRC, Nat. Acad. Sci., Washington, DC.

Oba, M., and M. S. Allen. 2003. Effects of corn grain conservation method on feeding behavior and productivity of lactating dairy cows at two dietary starch concentrations. J. Dairy Sci. 86:174183

Reynal, S. M., and G. A. Broderick. 2003. Effects of feeding dairy cows protein supplements of varying ruminal degradability. J. Dairy Sci. 86:835-843.

Reynolds, C. K., S. B. Cammell, D. J. Humphries, D. E. Beever, J. D. Sutton, and J. R. Newbold. 2001. Effects of postrumen starch infusion on milk production and energy metabolism in dairy cows. J. Dairy Sci. 84:2250-2259.

Van Soest, P. J., J. B. Robertson, and B. A. Lewis. 1991. Methods for dietary fiber, neutral detergent fiber, and nonstarch polysaccharides in relation to animal nutrition. J. Dairy Sci. 74:3583-3597.

Weiss, W. P., N. R. St-Pierre, and L. B. Willett. 2009. Varying type of forage, concentration of metabolizable protein, and source of carbohydrate affects nutrient digestibility and production by dairy cows. J. Dairy Sci. 92:5595-5606.

Wu, Z., and L. D. Satter. 2000. Milk production during the complete lactation of dairy cows fed diets containing different amounts of protein. J. Dairy Sci. 83:1042-1051. 